\title{
OLFACTORY MARKER PROTEIN: TURNOVER AND TRANSPORT IN NORMAL AND REGENERATING NEURONS ${ }^{1}$
}

\author{
RICHARD M. KREAM ${ }^{2}$ AND FRANK L. MARGOLIS ${ }^{3}$ \\ Roche Institute of Molecular Biology, Roche Research Center, Department of Physiological Chemistry and Pharmacology, \\ Nutley, New Jersey 07110
}

Received May 19, 1983; Revised August 22, 1983; Accepted August 22, 1983

\begin{abstract}
A 19,000-dalton acidic protein designated olfactory marker protein (OMP) is a cell-specific marker of mature olfactory chemosensory neurons. Intranasal irrigation of mouse olfactory epithelium with $\left[{ }^{35}\right.$ S]methionine labeled OMP to high specific activity. Turnover and transport characteristics of ${ }^{35} \mathrm{~S}$-labeled OMP were compared to those of ${ }^{35} \mathrm{~S}$-labeled global cytosol protein in groups of young, adult, and Triton-treated adult mice. The latter contained primarily large numbers of regenerating olfactory neurons.

In olfactory epithelium of young and Triton-treated mice, the specific activity of OMP was three times that of global cytosol protein, whereas in adults the two measures were equal. In all three groups, however, the rate of degradation of OMP was roughly equal to that of cytosol protein $\left(T_{1 / 2}\right.$ $=5$ to 6 days). By contrast, differences in $T_{1 / 2}$ for OMP decline in the bulb of adult, young, and Triton-treated adult mice were highly significant $\left(T_{1 / 3}\right.$ 's of $9.3,6.1$, and 4 to 5 days, respectively; $p=$ 0.001 ). The specific activity of $\left[{ }^{35} \mathrm{~S}\right]$ methionine incorporated in OMP exceeded that of the free amino acid 5-fold, indicating minimal precursor reutilization during the course of our experiments. Turnover data indicate that increased isotope incorporation into OMP in the epithelium is matched by an accelerated rate of degradation in the bulb. This may be correlated with the physiological state or developmental age of the primary neurons since in young and Triton-treated adult mice, rapidly maturing "young" olfactory neurons represent a larger proportion of the total population than in adults. Thus, OMP behaves as a typical, relatively slowly transported soluble protein $(v=$ 2 to $4 \mathrm{~mm} /$ day, slow component $b$ ).
\end{abstract}

Margolis and co-workers have reported the isolation and characterization of a soluble, low molecular weight acidic protein from the olfactory tissues of two rodent species (mouse and rat) (Margolis, 1972; Keller and Margolis, 1976). Antisera raised against the proteins cross-react with extracts of olfactory tissues from a wide variety of vertebrate species (Keller and Margolis, 1975). Subsequent immunohistochemical studies (Hartman and Margolis, 1975; Monti-Graziadei et al., 1977) demonstrated that the protein is localized in primary olfactory

\footnotetext{
${ }^{1}$ Preliminary accounts of this study were presented at the American Society for Neurochemistry (1982) and the Society for Neuroscience (1982). We wish to thank Mr. Larry Brink for performing the amino acid analyses, Mr. Tom Lewinson, Dr. R. White, and Dr. Frank Hsieh of the Department of Biostatistics, Hoffman-La Roche, for statistical analyses, and Ms. Ann Trbovich for secretarial assistance.

${ }^{2}$ Current address: Department of Anesthesiology, Tufts-New England Medical Center, Boston, MA 02111.

${ }^{3}$ To whom all correspondence should be addressed.
}

receptor neurons in the olfactory epithelium and in their axons and terminals in the glomerular layer of the olfactory bulb. During ontogeny, the protein appears in receptor neurons during the last trimester of gestation and reaches adult levels approximately 1 month postnatally (Farbman and Margolis, 1978, 1980; Monti-Graziadei et al., 1980). These observations, coupled with other data (see Margolis 1980, 1982 for review), have demonstrated that this protein, termed olfactory marker protein (OMP), is an example of cell-specific gene expression and serves as an unique marker of mature olfactory chemosensory neurons. Primary olfactory chemoreceptor neurons undergo continual turnover and replacement from stem cells during the lifetime of an individual (Graziadei, 1973; Graziadei and Monti-Graziadei, 1978). These cells mature and reinnervate the olfactory bulb after chemical or surgical lesion (Harding et al., 1977; Nadi et al., 1981).

${ }^{3} \mathrm{H}$-amino acids are incorporated into OMP in explants of olfactory epithelium but not olfactory bulb (Margolis 
and Tarnoff, 1973). These observations, coupled with the ontogenetic studies (see above), strongly suggested local synthesis of OMP in neuronal perikarya and its transport by axoplasmic flow to nerve terminals in the olfactory bulb. We now demonstrate the in vivo incorporation of $\left[{ }^{35} \mathrm{~S}\right]$ methionine into OMP following intranasal irrigation of mouse olfactory epithelium and report its rate of turnover and transport in normal and regenerating mouse olfactory neurons.

\section{Materials and Methods}

$\left[{ }^{35} \mathrm{~S}\right]$ Methionine $(1000$ to $1200 \mathrm{Ci} / \mathrm{mmol}$ in $10 \mathrm{mM}$ aqueous 2-mercaptoethanol) was obtained from New England Nuclear (Boston, MA). Carrier-free $\mathrm{Na}^{125} \mathrm{I}$ (17 $\mathrm{Ci} / \mathrm{mg}$ in $0.1 \mathrm{M} \mathrm{NaOH}$ ) was obtained from AmershamSearle (Arlington Hgts, IL). All chemicals and solvents were of analytical grade. Nonradioactive amino acids, lactoperoxidase (purified grade), and phenylmethyl sulfonyl fluoride (PMSF) were purchased from Calbiochem (La Jolla, CA). Pepstatin A, trasylol, acrylamide, Coomassie brilliant blue G250, SDS, Triton X-100, and BSA were from Sigma Chemical Co. (St. Louis, MO). $N, N, N^{\prime}, N^{\prime}$-Tetramethyl-ethylenediamine (TEMED), 2mercaptoethanol, $N, N^{\prime}$-methylene-bisacrylamide (bisacrylamide), silver nitrate, Kodak Rapid Fixer, and Kodak Photographic Clearing Solution were from Eastman Kodak (Rochester, NY). Ammonium persulfate, $25 \%$ glutaraldehyde, $30 \%$ hydrogen peroxide, and 5-sulfosalicylic acid were obtained from Fisher (Fairlawn, NJ). Hydrofluor was purchased from National Diagnostics (Somerville, NJ). Ultrogel $A_{c} A 54$, and $A_{c} A 202$ were from $L K B$ (Rockville, MD). Donkey anti-goat immunoglobulins immobilized on Kynar beads were obtained from Roche Diagnostics (Nutley, NJ). Mouse OMP was purified as described (Margolis, 1980), with a final gel filtration step over Ultrogel $\mathrm{A}_{\mathrm{c}} \mathrm{A} 54$. Goat antiserum to OMP was from previous bleedings (Keller and Margolis, 1975).

Labeling of olfactory epithelial proteins. CD-1 female mice (adult exbreeder and young animals 5 to 6 weeks of age) were obtained from Charles River Laboratories and given free access to Purina Chow and water. The animals were maintained on a 12 -hr night/day cycle. $\beta$-Mercaptoethanol was removed from $\left[{ }^{35} \mathrm{~S}\right]$ methionine in $0.9 \%$ $\mathrm{NaCl}$ under a stream of dry $\mathrm{N}_{2}$. The final concentration of working isotope was $100 \mu \mathrm{M}$ in $0.9 \% \mathrm{NaCl}$ with a specific activity of 60 to $70 \mathrm{Ci} / \mathrm{mmol}$. Each mouse received a total of $300 \mu \mathrm{Ci}$ of precursor by bilateral intranasal irrigation similar to the procedure described by Margolis and Grillo (1977). The isotope was administered in two $20-\mu$ l aliquots with a 20 -min rest period between the left and right irrigations. By this labeling procedure, 2 to $5 \%$ of injected isotope was incorporated into ccllular protein.

Preparation of tissue extracts. Mice were killed by $\mathrm{CO}_{2}$ asphyxiation followed by exsanguination at various time intervals after labeling with $\left[{ }^{35} \mathrm{~S}\right]$ methionine. Olfactory epithelia and olfactory bulbs from each animal were dissected onto dry ice, weighed, and stored in a liquid $\mathrm{N}_{2}$ freezer. The tissues were homogenized by sonic disruption (Fisher dismembrator, microprobe setting No. 35) in $1 \mathrm{ml}$ of $150 \mathrm{mM} \mathrm{NaCl}, 20 \mathrm{~mm}$ Tris-HCl, $\mathrm{pH} 8.0$, buffer containing PMSF, trasylol, and pepstatin at $5 \mu \mathrm{g} / \mathrm{ml}$ each. After centrifugation at $100,000 \times g$ for $1 \mathrm{hr}$, the high-speed supernatant fractions were reserved. The particulate fractions were washed by resuspension and centrifugation in $1 \mathrm{ml}$ of homogenization buffer as above. Washed particulate fractions were finally solubilized in $1 \mathrm{ml}$ of SDS sample buffer (see below).

Measurement of global protein. For total counts per minute, duplicate $30-\mu \mathrm{l}$ aliquots of high-speed supernatants and solubilized particulate fractions were added to $1 \mathrm{ml}$ of $\mathrm{H}_{2} \mathrm{O}$ and $1 \mathrm{ml}$ of SDS sample buffer and counted in $12 \mathrm{ml}$ of Hydrofluor in a Beckman LS-100 liquid scintillation spectrometer at an efficiency of 88 to $90 \%$ using $\left[{ }^{14} \mathrm{C}\right]$ toluene as an internal standard. For acidprecipitable counts per minute, identical $30-\mu \mathrm{l}$ aliquots were added to $1 \mathrm{ml}$ of $5 \%$ sulfosalicylic acid (SSA) containing $100 \mu \mathrm{g}$ of BSA, $100 \mu \mathrm{M}$ nonradioactive methionine (and $100 \mathrm{mM} \mathrm{KCl}$ for solubilized membranes). After $16 \mathrm{hr}$ at $4^{\circ} \mathrm{C}$, protein pellets were collected and washed by resuspension in $1 \mathrm{ml}$ of $5 \%$ SSA and recentrifugation. This precipitated protein was solubilized in $1 \mathrm{ml}$ of SDS sample buffer $\left(6 \mathrm{hr}, 50^{\circ} \mathrm{C}\right)$ added to $1 \mathrm{ml}$ of $\mathrm{H}_{2} \mathrm{O}$ and counted in $12 \mathrm{ml}$ of Hydrofluor as described. Total protein content was measured by the dye-binding method of Sedmak and Grossberg (1977) using Coomassie brilliant blue G250 and crystalline BSA as standard.

Measurement of OMP specific activity. Quantitative immunoprecipitations were performed by a modification of the procedure of Keller and Margolis (1975) using a specific goat antiserum to OMP. Aliquots of high-speed supernatant from olfactory epithelia $(250 \mu \mathrm{l})$ and olfactory bulbs $(500 \mu \mathrm{l})$, were diluted to $1 \mathrm{ml}$ with $150 \mathrm{mM}$ $\mathrm{NaCl}, 20 \mathrm{~mm}$ Tris-HCl buffer, $\mathrm{pH} 8.0$, in 1.5 -ml microfuge tubes (total protein approximately $500 \mu \mathrm{g}$ per tube), and $100 \mu \mathrm{l}$ of goat antiserum were added. After $72 \mathrm{hr}$ at $4^{\circ} \mathrm{C}$, the immunoprecipitates were collected by centrifugation at $12,000 \times g$ in an Eppendorf microfuge. Precipitates were washed in $1 \mathrm{ml}$ of reaction buffer for $30 \mathrm{~min}$ at $4^{\circ}$ and recentrifuged for $15 \mathrm{~min}$. Repeated washings resulted in somewhat lower yields of immunoprecipitated OMP.

Washed immunoprecipitates were solubilized in $50 \mu \mathrm{l}$ of SDS sample buffer without $\beta$-mercaptoethanol by boiling for $10 \mathrm{~min}$. After cooling, $10 \mu \mathrm{l}$ of $8 \mathrm{M}$ urea containing $0.01 \%$ bromphenol blue were added to each tube. The samples were resolved on SDS polyacrylamide gels as described below. By our procedure, $100 \mu \mathrm{l}$ of antiserum were sufficient to immunoprecipitate 1 to $2 \mu \mathrm{g}$ of OMP. Nonimmune goat serum did not precipitate an electrophoretic band corresponding to OMP. Addition of a 10 -fold excess of purified OMP to quantitative immunoprecipitations reduced the labeled OMP in the precipitates by $80 \%$ (data not shown).

Polyacrylamide gel electrophoresis. Analytical SDS polyacrylamide gel electrophoresis was performed according to Neville (1971) as modified by Chiu et al. (1980) using $9 \times 14 \times 0.15 \mathrm{~cm}$ slab gels (Hoefer SE 500 slab gel unit, Hoefer Scientific, San Francisco, CA). The separating gel was a 10 to $20 \%$ exponential gradient of acrylamide (constant 3.0\% bisacrylamide cross-linker). This system clearly resolved OMP from other components of the dissociated immunoprecipitates.

The gradients were poured at the rate of $3 \mathrm{ml} / \mathrm{min}$ 
using a Rabbit peristaltic pump (Rainin) connected to a gradient maker with a sealed front chamber. The stacking gel which consisted of $4.65 \%$ acrylamide monomer, $3.2 \%$ cross-linker in $0.027 \mathrm{M} \mathrm{H}_{2} \mathrm{SO}_{4}, 0.054 \mathrm{M}$ Tris, $\mathrm{pH}$ 6.1 was immediately layered at the rate of $2 \mathrm{ml} / \mathrm{min}$. Polymerization was effected by $0.05 \%$ TEMED, $0.03 \%$ ammonium persulfate. Protein samples were dissolved in SDS sample buffer consisting of $0.05 \mathrm{M}$ Tris- $\mathrm{HCl}, \mathrm{pH}$ $6.8,1 \%$ SDS, $10 \%$ glycerol, with or without $2 \% \beta$-mercaptoethanol. The upper reservoir buffer was $0.04 \mathrm{M}$ Trisborate), $0.1 \%$ SDS, $0.001 \mathrm{M} \mathrm{Na}$ EDTA, $\mathrm{pH}$ 8.6; the separating gel and lower reservoir buffer was $0.42 \mathrm{M}$ Tris$\mathrm{HCl}, \mathrm{pH}$ 9.2. Electrophoresis was performed at $20 \mathrm{~mA} /$ gel for $4 \mathrm{hr}$. Gels were fixed in $500 \mathrm{ml}$ of $50 \%$ methanol, $12 \%$ acetic acid, $6 \%$ glutaraldehyde for $2 \mathrm{hr}$ at $22^{\circ} \mathrm{C}$.

Modified silver stain. Protein bands were visualized by a modification of the silver stain procedure of Oakley et al. (1980). Fixed gels were transferred to 1 liter of $10 \%$ ethanol, $5 \%$ acetic acid in a glass tray. After $3 \mathrm{hr}$ of gentle shaking, during which there were three 1-liter solvent changes, gels were transferred to 1 liter of the same solution and held overnight at room temperature. The gels were then placed in $500 \mathrm{ml}$ of $50 \%$ methanol, $12 \%$ acetic acid, $6 \%$ glutaraldehyde. After $2 \mathrm{hr}$, the gels were transferred to 1 liter of $10 \%$ ethanol, $5 \%$ acetic acid in a large glass tray with gentle shaking. After three successive 1-liter changes of the latter solvent of $1 \mathrm{hr}$ each, the gels were placed in 1 liter of $\mathrm{H}_{2} \mathrm{O}$ for a total of 3 to $6 \mathrm{hr}$ with at least three $\mathrm{H}_{2} \mathrm{O}$ changes. The gels were then transferred to an ammoniacal silver solution consisting of $4 \mathrm{gm}$ of silver nitrate, $7 \mathrm{ml}$ of fresh concentrated ammonium hydroxide in $500 \mathrm{ml}$ of $0.08 \% \mathrm{NaOH}$. After $1 \mathrm{hr}$ of incubation at room temperature, the gels were transferred to 1 liter of $\mathrm{H}_{2} \mathrm{O}$ for $30 \mathrm{~min}$ and then to 800 $\mathrm{ml}$ of $0.005 \%$ citric acid, $0.02 \%$ formaldehyde. After this reduction, the stained gels were fixed in $400 \mathrm{ml}$ of Kodak Rapid Fixer, followed by $500 \mathrm{ml}$ of Kodak Clearing Solution, and transferred to 1 liter of $\mathrm{H}_{2} \mathrm{O}$ for scanning and photography.

Quantitation of OMP from SDS gels. Densitometric scans of stained gels were made using a Zeineh soft laser densitometer (LKB). Protein content of each resolved OMP band was quantitated by comparison against purified OMP standards electrophoresed at three concentrations. Peak area was proportional to OMP content in the range of 0.5 to $5 \mu \mathrm{g}$ of protein. The OMP bands and the two unstained gel slices surrounding each OMP band were excised and digested in $1 \mathrm{ml}$ of $15 \% \mathrm{H}_{2} \mathrm{O}_{2}$ for $16 \mathrm{hr}$ at $70^{\circ} \mathrm{C}$ in sealed scintillation vials. After cooling, $1 \mathrm{ml}$ of $\mathrm{H}_{2} \mathrm{O}$ and $12 \mathrm{ml}$ of Hydrofluor were added to each vial, and radioactivity was quantitated in a liquid scintillation spectrometer. Background radioactivity, expressed as the average of each pair of surrounding gel slices, was subtracted from total radioactivity in each OMP band. $\left.{ }^{35} \mathrm{~S}\right]$ Methionine radioactivity in OMP was expressed as counts per minute per microgram of protein.

Determination of $\left[^{35} S\right]$ methionine specific activity. 'The specific activity of $\left[{ }^{35} \mathrm{~S}\right]$ methionine incorporated in OMP was calculated from the predetermined OMP specific activity value (counts per minute per microgram of protein). OMP is 19,000 daltons, contains $3 \mathrm{~mol}$ of methionine/mol of OMP, and lacks cysteine (Margolis, 1972).
Thus, $\left[{ }^{35} \mathrm{~S}\right]$ methionine specific activity was expressed as counts per minute per picomole of methionine incorporated in OMP. The specific activity of free $\left[{ }^{35}\right.$ S $]$ methionine was determined from acid-soluble extracts of highspeed supernatants from olfactory epithelia. Amino acid analyses were performed as previously described with Fluorescamine (Stein et al., 1973). Free methionine content was quantitated against a methionine standard with norleucine serving as internal standard. Eluant fractions (1 ml) were added to $1 \mathrm{ml}$ of $\mathrm{H}_{2} \mathrm{O}$ and $12 \mathrm{ml}$ of Hydrofluor, and radioactivity was monitored in a liquid scintillation counter. Specific activity of free $\left[{ }^{35} \mathrm{~S}\right]$ methionine was expressed as counts per minute per picomole of methionine.

Lesioning of adult mice with Triton $X-100$. Unanesthetized adult mice were given a single intranasal dose $(100 \mu \mathrm{l})$ of $0.7 \%$ Triton $\mathrm{X}-100$ in $0.9 \%$ saline. This lesioning procedure results in deafferentation of the olfactory bulb, followed by reinnervation within 30 days (Nadi et al., 1981). To radiolabel cellular proteins and OMP during the linear phase of return of biochemical neuronal markers, lesioned mice were given a bilateral intranasal dose of $\left[{ }^{35} \mathrm{~S}\right]$ methionine (see above) 19 days after Triton X-100 administration.

Radioimmunoassay of OMP. Mouse OMP was radiolabeled with ${ }^{125} \mathrm{I}$ using soluble lactoperoxidase (Kream et al., 1980). The specific activity of the tracer was 100 to $200 \mathrm{Ci} / \mathrm{mmol}$ as estimated by competitive displacement with nonradioactive OMP. Bound ${ }^{125}$ I-labeled OMP was separated from free tracer by donkey anti-goat immunoglobulins immobilized on Kynar beads. The sensitivity of the immunoassay was $50 \mathrm{pg}$ of OMP, and the $50 \%$ displacement point $\left(\mathrm{IC}_{50}\right)$ was $500 \mathrm{pg}$ of OMP.

Data analysis. Intraexperiment statistical analyses were performed on the slopes of time-dependent decline of radioactivity in OMP and global cytosol protein assuming first-order kinetics. The equation used was $\ln (y 2 / y 1)=a+b x+$ error, where $y 2$ and $y 1$ are OMP and global cytosol protein specific activities, respectively, and $x$ is time in hours. Analysis of variance (ANOVA) was used to test for nonlinearity for each of three hypotheses: (1) $a=0, b=0$;(2) $a \neq 0, b=0$;(3) $a=0, b$ $\neq 0$. Interexperiment analyses tested departures from parallelism of slope between the computer-generated regression lines for OMP decline and for global cytosol protein decline in all three groups of mice.

\section{Results}

Three groups of mice, adult, young (5 to 6 weeks of age), and Triton-treated adults received $\left[{ }^{35} \mathrm{~S}\right]$ methionine by bilateral intranasal irrigation. The specific activities of OMP and global cytosol protein were measured as a function of time in olfactory epithelium and bulb. The rates of turnover and transport of OMP and global cytosol protein were compared between the groups of mice.

Decline of ${ }^{35} \mathrm{~S}$-labeled $\mathrm{OMP}$ versus ${ }^{35} \mathrm{~S}$-labeled soluble total protein as a function of time in olfactory epithelium. OMP and epithelial cytosol proteins were labeled in vivo to high specific activities by intranasal irrigation of CD1 female mice with $\left[{ }^{35}\right.$ S]methionine (Fig. 1). The extent of isotope incorporation as measured by extrapolation of 


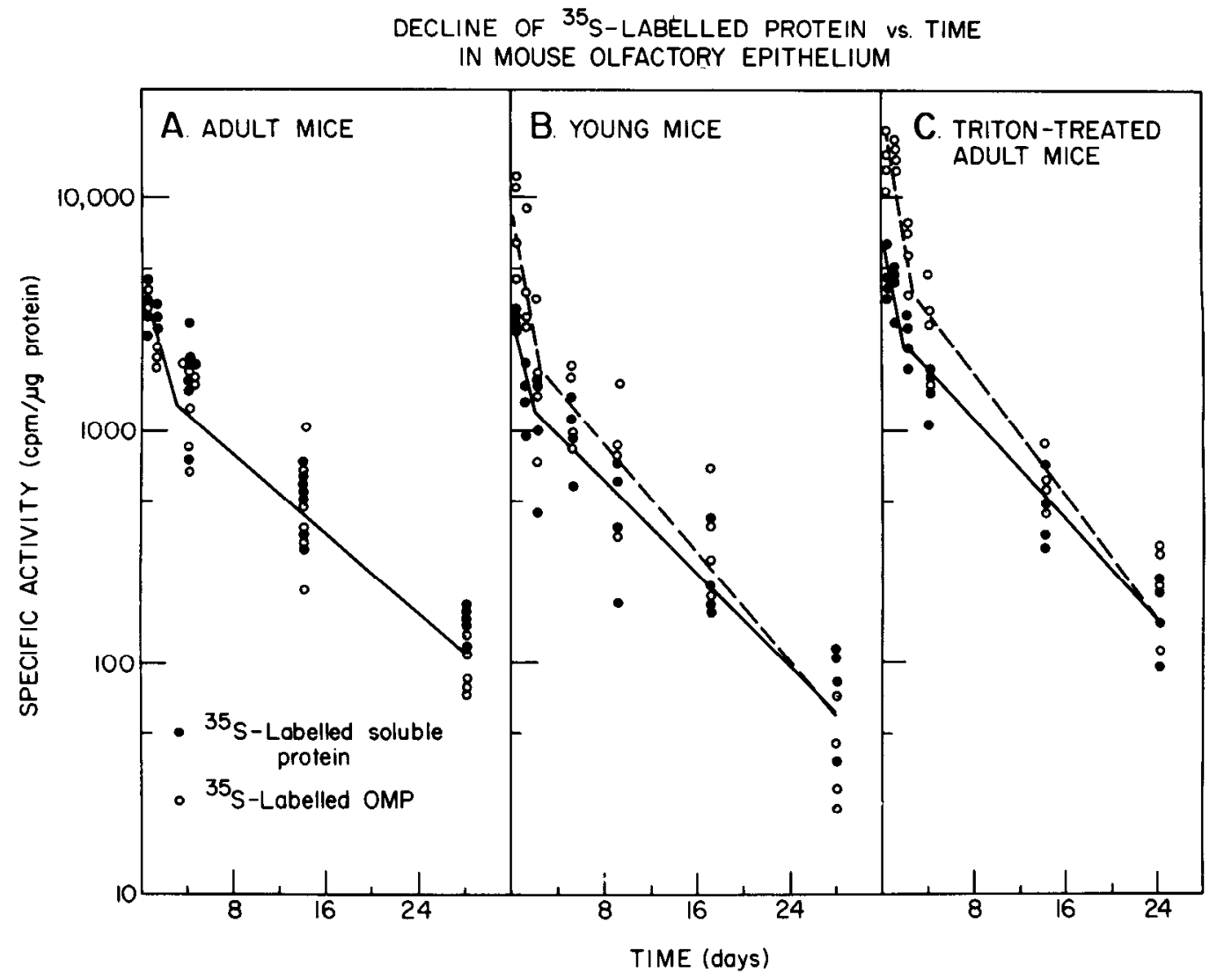

Figure 1. Decline of ${ }^{35} \mathrm{~S}$-labeled OMP and ${ }^{35} \mathrm{~S}$-labeled global cytosol protein in the olfactory epithelium as a function of time for groups of $(A)$ adult, $(B)$ young ( 5 to 6 weeks of age), and $(C)$ Triton-treated adult mice. Specific activity values were measured as described in the text, and data points represent individual animals. Computer regression analysis of the linear portion of each curve (between 2 and 28 days) yielded apparent $T_{1 / 2}$ 's for decline of global cytosol protein of $(A) 6.8$ days, $(B) 6.8$ days, and $(C)$ 5.7 days. The corresponding values for OMP were $(A) 6.4$ days, $(B) 4.9$ days, and $(C) 4.8$ days. Between groups, differences in $T_{1 / 2}$ for both OMP and global protein decay were found not statistically significant. The equations of the regression lines for global proteins were $(A) \ln y=-0.00426 x+7.8542 ;(B) \ln y=-0.00425 x+7.2464 ;(C) \ln y=-0.00506 x+7.7744$. Those for OMP were $(A) \ln y=-0.00454 x+7.9215 ;(B) \ln y=-0.00592 x+7.7419 ;(C) \ln y=-0.00606 x+8.5757$.

the early portion of each line back to zero time yielded specific activity values of approximately $3500 \mathrm{cpm} / \mu \mathrm{g}$ of protein, $3000 \mathrm{cpm} / \mu \mathrm{g}$ of protein, and $5000 \mathrm{cpm} / \mu \mathrm{g}$ of protein for global cytosol proteins in adult mice, young mice (5 to 6 weeks of age), and Triton-treated adult (regenerating) mice, respectively. The corresponding specific activity values for OMP were approximately $4000 \mathrm{cpm} / \mu \mathrm{g}$ of protein, $8500 \mathrm{cpm} / \mu \mathrm{g}$ of protein, and $18,000 \mathrm{cpm} / \mu \mathrm{g}$ of protein for adult, young, and Tritontreated adult mice, respectively. An index of biosynthetic activity was obtained by comparing the specific activity ratios of $\mathrm{OMP} /$ cytosol protein extrapolated to zero time for each group of mice. These values were 1.0, 2.8, and 3.5 for adult, young, and adult regenerating mice, respectively. Thus, although incorporation into total cytosol protein was stimulated, the incorporation of isotope into OMP was shown to be differentially enriched in young and 'Triton-treated (regenerating) animals compared to normal adult animals.

For all three groups of mice, the apparent decay of both OMP and global cytosol protein was biphasic, comprising a fast phase ( $T_{1 / 2}$ of approximately 1 day) and a slow phase. In each instance only the slow phase was amenable to statistical analysis by simple linear regression. Between 2 and 28 days, global protein specific activities were shown to undergo first-order decline with apparent $T_{1 / 2}$ 's of 6.8 days, 6.8 days, and 5.7 days for adult, young, and Triton-treated adult (regenerating) mice, respectively. The corresponding $T_{1 / 2}$ 's for first-order decline of OMP were 6.4 days, 4.9 days, and 4.8 days for adult, young, and Triton-treated (regenerating) animals, respectively. These data indicate that in the olfactory epithelium of adult mice, the rate of OMP decline was equal to the rate of cytosol protein decline. In contrast, in both young and Triton-treated (regenerating) mice, the rate of OMP decline is significantly greater than that of cytosol protein. Between groups, half-lives for OMP decline are not statistically significantly different. Average intergroup half-lives for OMP and global cytosol protein turnover are 5.3 and 6.4 days, respectively. These data demonstrate increased isotope incorporation into OMP in the olfactory epithelium of young and Tritontreated (regenerating) mice as compared to adult mice. This greater incorporation was matched by an increased rate of OMP turnover relative to global protein turnover. Accumulation and decline of ${ }^{35} S$-labeled OMP versus 
${ }^{35} S$-labeled soluble total protein as a function of time in olfactory bulb. The time course of protein turnover in olfactory bulb was found to be composed of two distinct phases: an accumulation of ${ }^{35} \mathrm{~S}$-labeled protein followed by a relatively slow decline (Fig. 2). At early time points, ${ }^{35} \mathrm{~S}$-labeled OMP and ${ }^{35} \mathrm{~S}$-labeled soluble proteins were observed to accumulate linearly after a methionine pulse in the olfactory epithelium. Peak specific activities for OMP and global soluble protein were reached at 4 days, 2 days, and 1 day for adult, young, and Triton-treated adult (regenerating) mice, respectively. Maximal specific activity values were approximately $400 \mathrm{cpm} / \mu \mathrm{g}$ of protein, $400 \mathrm{cpm} / \mu \mathrm{g}$ of protein, and $500 \mathrm{cpm} / \mu \mathrm{g}$ of protein for global soluble protein, and $3000 \mathrm{cpm} / \mu \mathrm{g}$ of protein, $3500 \mathrm{cpm} / \mu \mathrm{g}$ of protein, and $5000 \mathrm{cpm} / \mu \mathrm{g}$ of protein for $\mathrm{OMP}$ in adult, young, and Triton-treated (regenerating) mice, respectively. Thus, OMP specific activity values exceeded those for global cytosol protein 4- to 5-fold, 8to 10 -fold, and 10- to 12 -fold in adult, young, and Triton- treated (regenerating) mice, respectively. After maximal values were attained, both OMP and global soluble protein specific activities exhibited first-order decay over a time span of approximately 24 days. The apparent $T_{1 / 2}$ 's for decay of cytosol protein in bulb were 8.3 days, 11.4 days, and 7.8 days for adult, young, and Triton-treated (regenerating) mice, respectively. The corresponding $T_{1 / 2}$ 's for decay of OMP were 9.3 days, 6.1 days, and 4.5 days for adult, young, and Triton-treated (regenerating) mice, respectively. These $T_{1 / 2}$ 's for OMP and global cytosol protein were not significantly different in adult mice; however, in both young and Triton-treated (regenerating) mice the decline of OMP was significantly more rapid than that of cytosol protein $(p=0.001)$. Intergroup differences in global protein turnover in the bulb were only marginally significant ( $p=0.04$, adult versus young; $p=0.66$, adult versus regenerating; $p=0.02$ young versus regenerating; with an overall average $T_{1 / 2}$ of 9.3 days). In sharp contrast, intergroup differences in OMP turnover ACCUMULATION AND DECLINE OF ${ }^{35}$ S-LABELLED PROTEIN
IN MOUSE OLFACTORY BULB

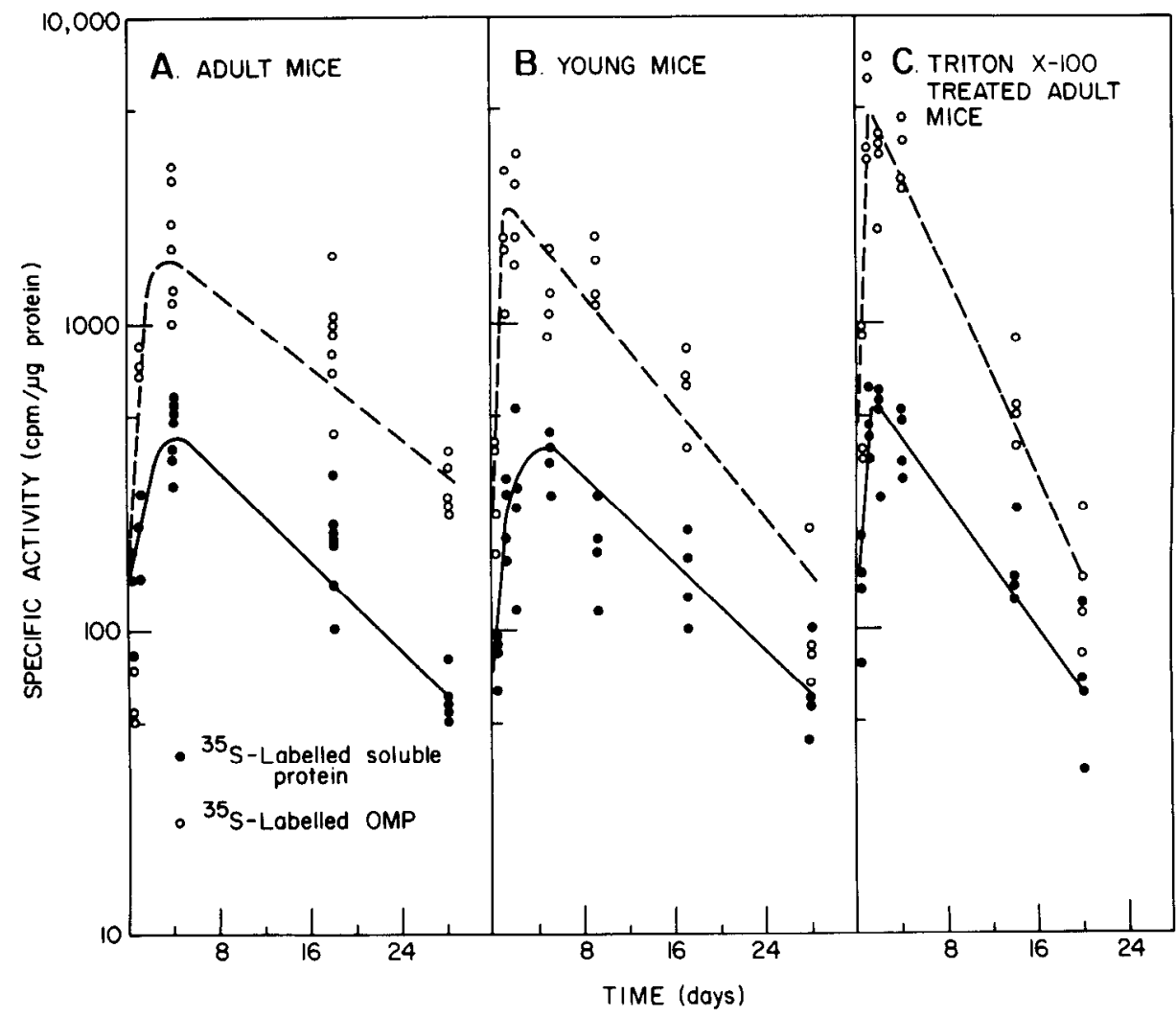

Figure $2 .{ }^{35} \mathrm{~S}$-labeled OMP and ${ }^{35} \mathrm{~S}$-labeled global cytosol protein accumulation and decline in the olfactory bulb as a function of time for groups of $(A)$ adult, $(B)$ young $(5$ to 6 weeks of age), and $(C)$ Triton-treated mice. Analyses were performed on olfactory bulbs from the same animals described in Figure 1. At early time points, ${ }^{35} \mathrm{~S}$-labeled protein was observed in accumulate linearly after methionine pulse in the epithelium, indicative of axoplasmic flow. Computer regression analyses performed on the linear phases of decline of approximately 24 days yielded apparent $T_{1 / 2}$ 's for decay of global cytosol protein of $(A) 8.3$ days, $(B)$ 11.4 days, and $(C) 7.8$ days. The corresponding values for OMP were $(A) 9.3$ days, $(B) 6.1$ days, and $(C) 4.5$ days. Intergroup differences in OMP turnover were highly significant $(p=0.001)$. The equations of the regressions lines for global protein turnover were $(A) \ln y=-0.00349 x+6.2965 ;(B) \ln y=-0.00253 x+6.0699 ;(C) \ln y=-0.00370 x+6.1789$. Those for OMP were $(A) \ln y=-0.00311 x+8.2835 ;(B) \ln y=-0.00474 x+7.9802 ;(C) \ln y=-0.00645 x+8.1876$. Statistical analyses of the intercepts of the regression lines showed OMP specific activities enriched versus global protein values by $(A) 5$-fold, $(B) 8$ - to 10 -fold, and $(C) 10$ - to 12 -fold. 
CHANGE OF ${ }^{35}$ S-OMP SPECIFIC ACTIVITY vs. TIME IN OLFACTORY TISSUES

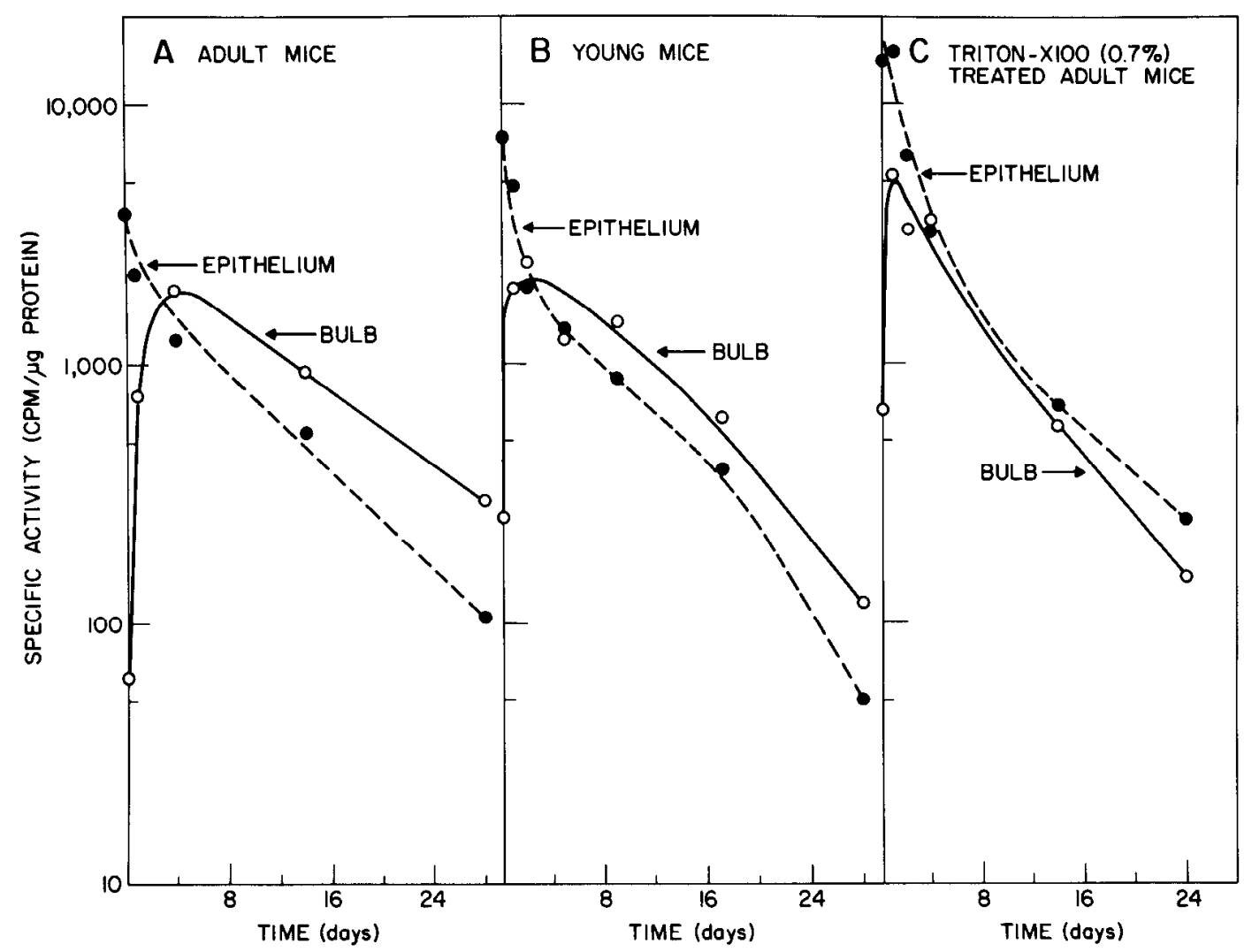

Figure 3. Time-dependent change of ${ }^{35} \mathrm{~S}$-labeled OMP specific activity in olfactory epithelium compared to olfactory bulb in $(A)$ adult, $(B)$ young, and $(C)$ Triton-treated mice. Points represent the means of data at each time point in Figures 1 and 2 . In the epithelium, the $T_{1 / 2}$ values for ${ }^{35} \mathrm{~S}$-labeled OMP degradation are $(A) 6.4$ days, $(B) 4.9$ days, and $(C) 4.8$ days. In the bulb, the corresponding values are $(A) 9.3$ days, $(B) 6.1$ days, and $(C) 4.5$ days.

were found to be highly significant ( $p=0.001$, all cases). Thus, these data demonstrate major differences in OMP turnover in the bulb among groups of adult, young, and Triton-treated mice. These data further indicate that OMP is a major axonally transported protein in primary chemoreceptor neurons, constituting approximately $5 \%$ of the radiolabeled protein in adult bulb, $10 \%$ in young bulb, and greater than $10 \%$ of the radiolabeled protein in Triton-treated adult (regenerating) bulbs.

In separate experiments, OMP labeled with $\left[{ }^{3} \mathrm{H}\right] \mathrm{leu}-$ cine or $\left[{ }^{3} \mathrm{H}\right] l y s i n e$ displayed similar decay profiles to ${ }^{35} \mathrm{~S}-$ labeled OMP in adult animals (data not shown). The scatter of the data, however, was considerably greater than with ${ }^{35} \mathrm{~S}$-labeled OMP, probably due to more efficient pulse labeling of the intracellular-free methionine pool and to the lack of cysteine in OMP. In addition, epithelial concentrations of free methionine were 10 to $20 \%$ of tissue leucine or lysine (Margolis, 1974), facilitating more rapid equilibration between intra- and extracellular $\left[{ }^{35}\right.$ S $]$ methionine specific activities.

Dynamics of ${ }^{35}$ S-labeled OMP turnover in olfactory epithelium verus olfactory bulb. The change of ${ }^{35} \mathrm{~S}$-labeled OMP specific activity versus time in olfactory tissues for groups of adult, young, and Triton-treated (regenerating) mice is illustrated in Figure 3. In the epithelium, the rapid phase of OMP decline at early time points was mirrored by the rapid phase of OMP accumulation in the olfactory bulb. The absolute amount of ${ }^{35} \mathrm{~S}$-labeled OMP lost during the rapid phase of decline in the epithelium was observed to be roughly equal to the ${ }^{35} \mathrm{~S}$-labeled OMP accumulated in the bulb at early time points. These calculations assumed an epithelial to bulb OMP pool ratio of approximately $2: 1$, as previously determined by radioimmunoassay (data not shown).

The relative turnover of OMP in olfactory bulb versus olfactory epithelium was assessed from the ratio of decay constants (OMP $T_{1 / 2}$ in the bulb/OMP $T_{1 / 2}$ in the epithelium). These relative decay values are $1.5,1.2$, and 0.9 for adult, young, and Triton-treated (regenerating) mice, respectively. Thus, OMP turnover in the bulb is significantly slower than in the epithelium in adult mice. In contrast, OMP turnover in the bulb is slightly faster than in the epithelium in Triton-treated (regenerating) mice.

The corresponding values for relative turnover of global cytosol protein in olfactory bulb compared to epithelium were $1.2,1.7$, and 1.4 for adult, young, and Triton-treated (regenerating) mice, respectively. In each group, cytosol protein was observed to turn over more slowly in the bulb than in the epithelium.

Accumulation and decline of ${ }^{35} \mathrm{~S}$-labeled particulatebound protein as a function of time in olfactory bulb of young mice. The time course of accumulation of ${ }^{35} \mathrm{~S}$ labeled particulate-bound protein in olfactory bulb of 
young mice was measured (Fig. $4 A$ ), and contrasted with that of ${ }^{35}$ S-labeled soluble protein in the same animals (Fig. $2 B$ ). Both particulate-bound and total soluble protein were observed to reach maximum specific activity values of approximately $400 \mathrm{cpm} / \mu \mathrm{g}$ of protein, then to undergo first-order decline with $T_{1 / 2}$ 's of 13.7 days and 11.4 days, respectively. In the bulb, ${ }^{35} \mathrm{~S}$-labeled particulate-associated proteins reached its maximum specific activity at least $24 \mathrm{hr}$ earlier than ${ }^{35} \mathrm{~S}$-labeled total soluble protein (Fig. $4 A$ versus Fig. $2 B$ ). Computer regression analysis of the ratio of specific activities indicated a sharp decline in ${ }^{35} \mathrm{~S}$-labeled particulate-bound versus ${ }^{35} \mathrm{~S}$ labeled total soluble protein at early time points (between 4.5 and $54 \mathrm{hr}$ ) consistent with rapid transport and turnover of a portion of the ${ }^{35} \mathrm{~S}$-labeled particulate fraction. As monitored by SDS gels, at $4.5 \mathrm{hr}$ after the methionine pulse, extensive ${ }^{35} \mathrm{~S}$-labeled in the 100,000 -dalton molec- ular weight range was evident in olfactory bulb particulates, indicating the presence of rapidly transported, high molecular weight, membrane-bound proteins in the mouse olfactory nerve (Fig. $4 B$ ).

Decline of $\left.{ }^{35} S\right]$ methionine specific activity as a function of time in olfactory epithelium. Reutilization of radiolabeled amino acid precursor has been demonstrated to result in significant overestimations of the apparent $T_{1 / 2}$ 's for decay of many proteins in biological systems (Poole, 1971; Glass and Doyle, 1972; Goldberg and Dice, 1974; Lajtha and Dunlop, 1981). Thus, the time course of decay of free $\left[{ }^{35} \mathrm{~S}\right]$ methionine in olfactory epithelium of both young and adult Triton-treated (regenerating) mice was measured and compared to the time course of decay of $\left[{ }^{35}\right.$ S]methionine incorporated into OMP in these same animals (Fig. 5). In young animals, regression lines generated from these data yielded specific activity values of
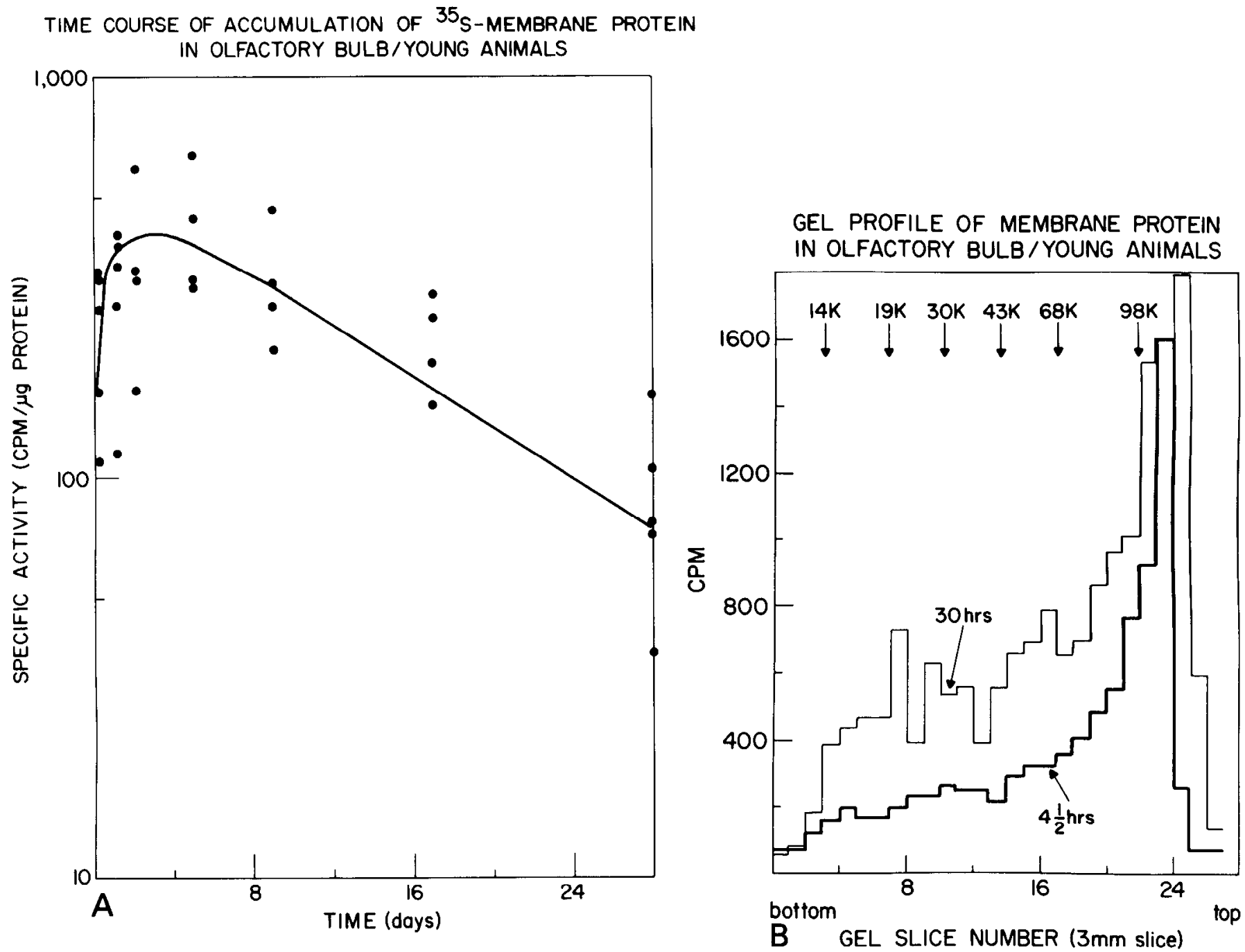

Figure 4. A, Time course of accumulation and decline of ${ }^{35} \mathrm{~S}$-labeled particulate-bound protein in olfactory bulb of young animals. Membrane-bound specific activity values were determined as described in the text. Data points represent individual animals. The $T_{1 / 2}$ for first-order decay measured between 2 and 28 days is 13.7 days as compared to 11.4 days for global soluble protein (Fig. $2 B$ ). The equation of the computer-generated regression line is $\ln y=-0.00211 x+6.0323$. $B$, Gel profile of particulate-bound protein at early times in olfactory bulb of young mice. Solubilized aliquots of particulate protein at 4.5 and 30 $\mathrm{hr}$ postlabeling were fractionated by SDS gel electrophoresis. Equal amounts of protein were loaded. Input radioactivity equaled 7,800 and $18,588 \mathrm{cpm}, 4.5$ and $30 \mathrm{hr}$, respectively. Radioactivity in $3-\mathrm{mm}$ gel slices was quantitated after $\mathrm{H}_{2} \mathrm{O}_{2}$ digestion as described in the text. At $4.5 \mathrm{hr}$, a major peak of ${ }^{35} \mathrm{~S}$-labeled protein is evident in the 100,000 -dalton region. 


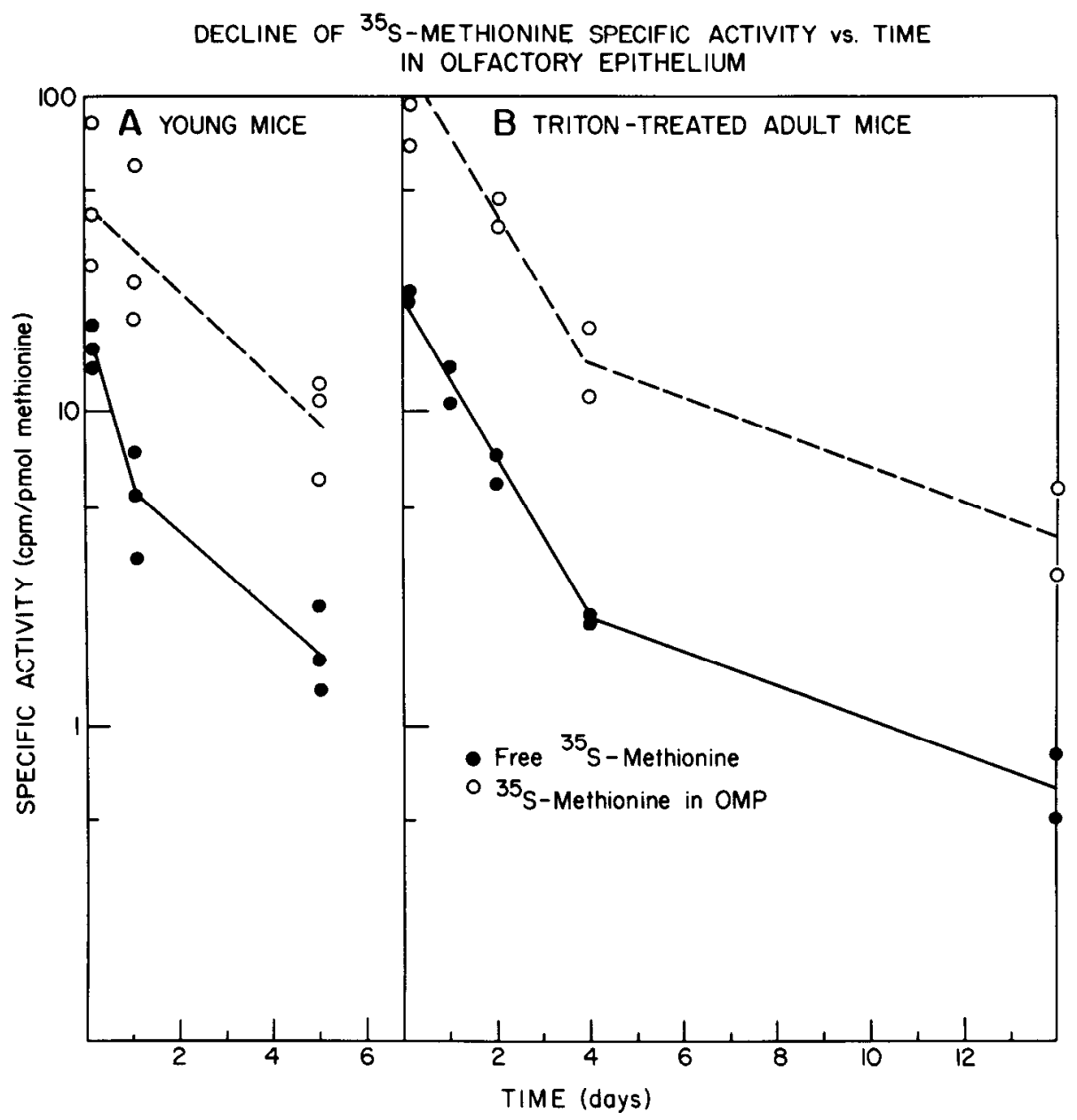

Figure 5. Decline of $\left[{ }^{35} \mathrm{~S}\right]$ methionine specific activity as a function of time in olfactory epithelium of $(A)$ young and $(B)$ Triton-treated mice. Points represent individual animals. In $A$, extrapolated regression lines yielded specific activity values of $47.6 \mathrm{cpm} / \mathrm{pmol}$ of methionine and $12.6 \mathrm{cpm} / \mathrm{pmol}$ of methionine for OMP and free methionine, respectively. For $B$, these values were $42.0 \mathrm{cpm} / \mathrm{pmol}$ and 6.51 $\mathrm{cpm} / \mathrm{pmol}$, respectively. Methionine specific activities were 4.2 times and 6.3 times higher in OMP than in free methionine over the time course of the experiments for $A$ and $B$, respectively. These differences were highly significant ( $p=0.002$ and $p=$ 0.001 , respectively) and indicated minimal precursor reutilization into OMP over the time course of our experiments.

$47.6 \mathrm{cpm} / \mathrm{pmol}$ of methionine and $12.6 \mathrm{cpm} / \mathrm{pmol}$ of methionine for $\left[{ }^{35} \mathrm{~S}\right]$ methionine in OMP and free $\left[{ }^{35} \mathrm{~S}\right]$ methionine, respectively. In Triton-treated (regenerating) animals, the corresponding values were $42.0 \mathrm{cpm} /$ $\mathrm{pmol}$ of methionine and $6.51 \mathrm{cpm} / \mathrm{pmol}$ of methionine, respectively. Statistical analysis of the intercepts of these regression lines demonstrated that the specific activity of $\left[{ }^{35} \mathrm{~S}\right]$ methionine in OMP was, on the average, 4.2 and 6.3 times higher than free $\left[{ }^{35} \mathrm{~S}\right]$ methionine in olfactory epithelium from young and regenerating mice, respectively. These differences were found to be highly significant ( $p=0.002$ and $p=0.001$, respectively). In contrast, the average slopes of the regression lines were found to be not significantly different from each other $(p=0.365$ and $p=0.957$, respectively). Although $\left[{ }^{35} \mathrm{~S}\right]$ methionine in OMP and free $\left[{ }^{35} \mathrm{~S}\right]$ methionine have been shown to decline at similar rates, the significant enrichment in absolute value of $\left[{ }^{35} \mathrm{~S}\right]$ methionine in OMP compared to free $\left[{ }^{35} \mathrm{~S}\right]$ methionine minimizes the effect of precursor reutilization on OMP $T_{1 / 2}$ measurements.

\section{Discussion}

The olfactory nerve was one of the first systems for studying axonal transport of radiolabeled molecules (Weiss and Holland, 1965; Gross and Beidler, 1973). We have now demonstrated that OMP is a major slowly transported protein in the mouse olfactory nerve whose turnover is dependent on the physiological state of the neurons. In the adult mouse, the transport velocity of OMP is estimated to be in the range of 2 to $4 \mathrm{~mm} /$ day based on the initial appearance of ${ }^{35} \mathrm{~S}$-labeled OMP in the bulb at $10 \mathrm{hr}$, assuming a length of 1 to $2 \mathrm{~mm}$ for the olfactory nerve. The mobility of OMP is thus the same as the complex of transported proteins designated slow component b (Garner and Lasek, 1982). This complex includes actin and soluble enzymes involved in interme- 
diary metabolism such as creatine phosphokinase (Willard et al., 1974; Brady et al., 1980; Tytell et al., 1981; see Grafstein and Forman, 1980 for review), calmodulin (Brady et al., 1980), neuron-specific enolase and 14-3-3 (Brady and Lasek, 1979; Erikson and Moore, 1980). In the rabbit visual system, these proteins were demonstrated to be transported at rates between $1.9 \mathrm{~mm} /$ day and $5.5 \mathrm{~mm} /$ day, to constitute about $3 \%$ of the axonally transported soluble protein each, and exhibit $T_{1 / 2}$ 's for decay of about 10 days (Erikson and Moore, 1980). These three parameters for OMP turnover and transport in the adult mouse (transport velocity of 2 to $4 \mathrm{~mm} /$ day, 4 to $5 \%$ of transported total soluble protein, $T_{1 / 2}$ of 9.3 days in the bulb) are very similar to those noted above for neuron-specific enolase and 14-3-3. Evaluation of SDS gel autoradiograms (data not shown), indicate that the majority of ${ }^{35} \mathrm{~S}$-labeled proteins were transported in slow component $\mathrm{b}$, including a low molecular weight, heatstable protein presumed to be calmodulin. Several other soluble proteins were shown to be transported at a slower velocity corresponding to slow component $a(v=0.3$ to $1 \mathrm{~mm} /$ day), corresponding to the transported microtubule-neurofilament complex (Tytell et al., 1981; see Grafstein and Forman, 1980 for review). Thus, OMP behaves as a slowly transported soluble protein in primary olfactory neurons. In contrast to OMP and other relatively slowly transported proteins, a class of fast transported proteins designated FC ( $v=200$ to $400 \mathrm{~mm} /$ day $)$ has been described in several systems consisting of membrane-associated integral proteins and glycoproteins (Willard et al., 1974; Cancalon and Flam, 1980; Tytell et al., 1981; Wenthold and McGarvey, 1982; see Grafstein and Forman, 1980 for review). By demonstrating rapid accumulation and decline of ${ }^{35} \mathrm{~S}$-labeled particulatebound protein in young mice (Fig. 4), slow transport of OMP can be clearly distinguished from rapidly transported proteins of the mouse olfactory pathway. The relative amount and rate of transported OMP are increased in young and Triton-treated (regenerating) adult mice compared to control adult mice. This is consistent with previous reports showing increases in velocity of slow transport and in the relative amounts of transported constituents in young versus adult animals (see Grafstein and Forman, 1980 for review) as well as a 3-fold increase in the amount and rate of slowly transported protein in regenerating goldfish optic axons (Grafstein, 1971; in Grafstein and Forman, 1980).

By contrast, increases in the relative amounts of fast transported material without changes of the rate of fast transport were observed in regenerating fish axons (Cancalon and Elam, 1980; McQuarrie and Grafstein, 1982). Thus, by these criteria as well, OMP behaves as a characteristic component of slow transport.

Our observations on the dynamics of OMP turnover and transport among groups of adult, young, and adult Triton-treated (regenerating) mice have been summarized in Table I and Figure 6. The extent of isotope incorporation into OMP in olfactory epithelium was about three times that of global soluble protein in both young and Triton-treated (regenerating) mice but equal to that of global cytosol proteins in adult mice. The time course of OMP decline in olfactory epithelium was bi-
TABLE I

Comparison of OMP synthesis, turnover, and transport in adult, young, and Triton-treated adult mice

\begin{tabular}{lcccc}
\hline & $\begin{array}{c}\text { Synthesis } \\
\text { (OMP Specific } \\
\text { Activity/Cytosol } \\
\text { Specific Activity) }\end{array}$ & $\begin{array}{c}T_{1 / 2} \\
\text { (Epithelium) }\end{array}$ & $\begin{array}{c}T_{1 / 2} \\
\text { (Bulb) }\end{array}$ & $\begin{array}{c}\text { Peak } \\
\text { OMP } \\
\text { (Bulb) }\end{array}$ \\
\hline Adult mice & 1.2 & days & days & days \\
Young mice & 2.7 & $1 ; 6.4$ & 9.3 & 4 \\
Triton-treated mice & 3.2 & $1 ; 4.9$ & 6.1 & 2 \\
\hline
\end{tabular}

phasic with the early rapid phase ( $T_{1 / 2} \cong 1$ day) being primarily newly synthesized ${ }^{35} \mathrm{~S}$-labeled OMP transported to nerve endings in the bulb without prior equilibration with the cytosol pool of OMP. The slow phase of OMP decline in olfactory tissues ( $T_{1 / 2}=5$ to 6 days) then would be defined as follows: (1) cellular breakdown of ${ }^{35} \mathrm{~S}$-labeled OMP in the perikarya of olfactory neurons in the epithelium and (2) breakdown of ${ }^{35} \mathrm{~S}$-labeled OMP previously transported to nerve endings in the olfactory bulb.

In the bulb, OMP accumulation is complementary to the rapid decline of OMP in the epithelium. OMP specific activities peak in the bulb at 4 days, 2 days, and 1 day for adult, young, and Triton-treated (regenerating) mice, respectively. After reaching maximum levels, bulb OMP specific activites undergo first-order decay with $T_{1 / 2}$ 's of 9.3 days, 6.1 days, and 4.5 days for these respective groups of mice.

The most dramatic differences in OMP turnover and transport between groups of mice were as follows.

(1) The increased isotope incorporation into $\mathrm{OMP}$ versus global protein in young and Triton-treated (regenerating) mice suggested either increased levels of OMP InRNA, increased synthetic rate of OMP, or possibly preferential loading of the $\left[{ }^{35} \mathrm{~S}\right]$ methionine precursor pool in the neurons (Fig. 6A). Modest changes in global protein synthetic activity were noted in the regenerating $(5000 \mathrm{cpm} / \mu \mathrm{g}$ of protein) versus adult $(3500 \mathrm{cpm} / \mu \mathrm{g}$ of protein) groups for a ratio of 1.4. These data indicate increased metabolic activity in all cell types of the epithelium during neuronal regeneration. However, the increase in OMP specific activity in these same groups of mice of $18,000 \mathrm{cpm} / \mu \mathrm{g}$ of protein versus $4,000 \mathrm{cpm} / \mu \mathrm{g}$ of protein, for a ratio of 4.5 , reflects the preferential expression of this specific protein or at least accelerated biosynthetic activity in the maturing neurons.

(2) There were greater levels of ${ }^{35} \mathrm{~S}$-labeled OMP in the epithelium of young and Triton-treated (regenerating) mice, resulting in higher relative specific activities of ${ }^{35} \mathrm{~S}$-labeled OMP in the bulb (8- to 10 -fold, 10- to 12 fold over global protein in young and Triton-treated (regenerating) mice, respectively, and earlier achievement of peak OMP specific activity relative to adult mouse bulb (Fig. 6B).

The relative turnover of OMP in the epithelium compared to the bulb in Triton-treated animals reflects a special case in which turnover at the nerve endings in the bulb has reached parity with turnover in the cell bodies in the epithelium. This relationship is also evident by comparing the time points at which OMP specific 
TIME COURSE OF OMP DECLINE IN OLFACTORY EPITHELIUM

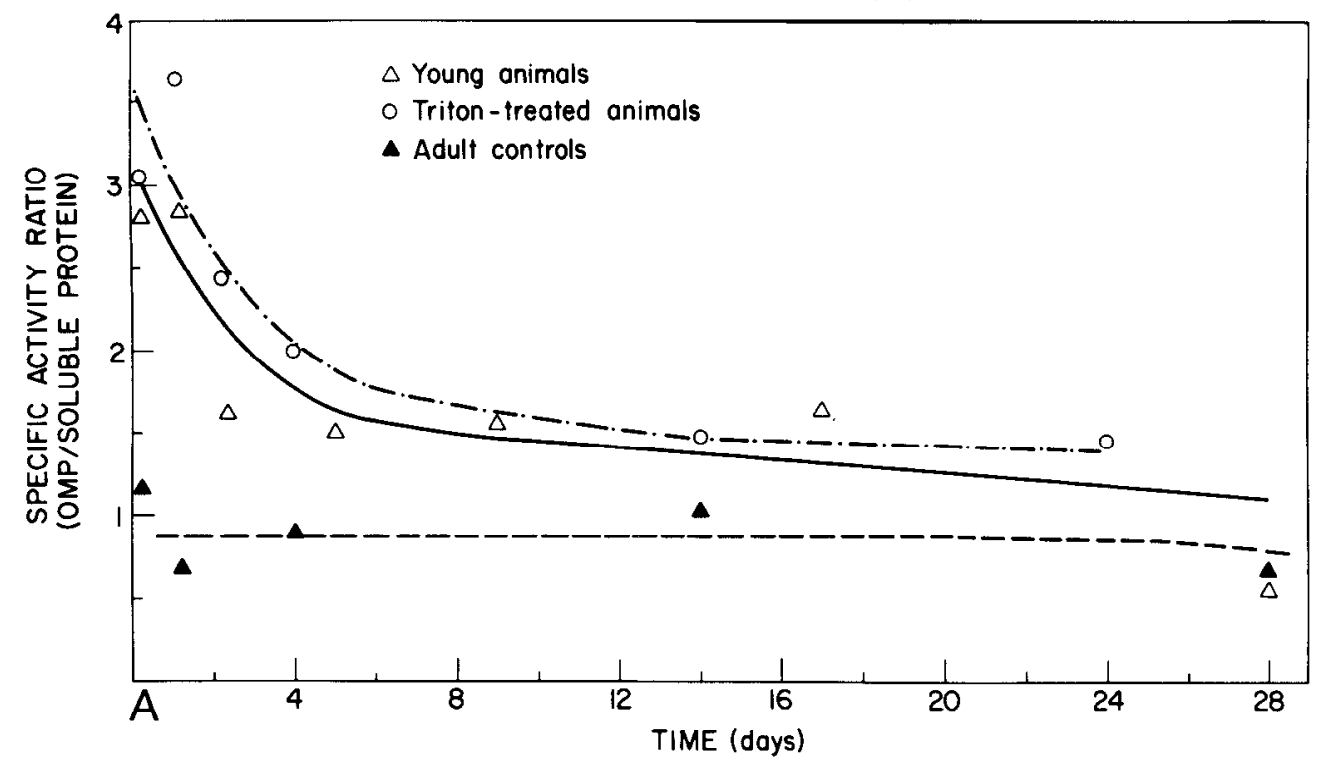

TIME COURSE OF OMP ACCUMULATION IN OLFACTORY BULB

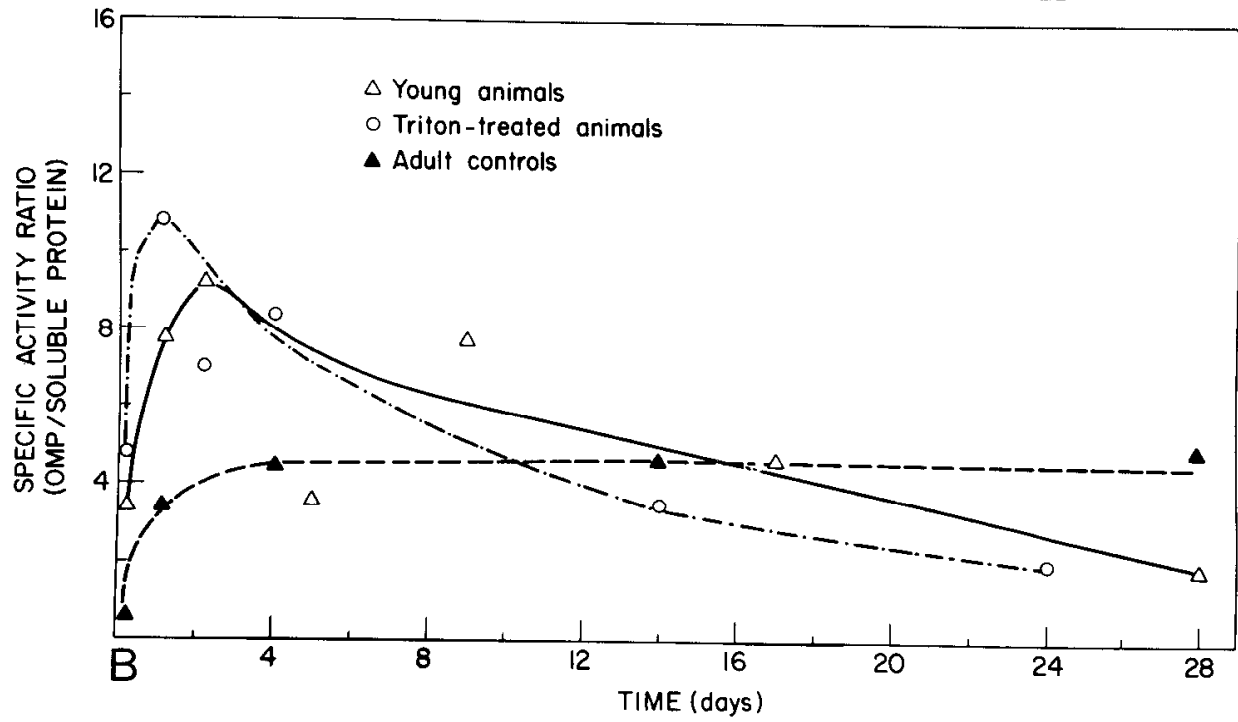

Figure 6. A, Time course of OMP decline relative to global soluble protein decline in olfactory epithelium. Data are extracted from Figure 1. Points represent the ratio of the means of OMP specific activity/soluble protein specific activity at various times. At early times, a dynamic phase of synthesis and turnover is evident in young and Triton-treated mice. $B$, Time course of OMP accumulation and decline relative to global soluble protein in olfactory bulb. Data are extracted from Figure 2. Points are as described in $A$.

activity in the bulb equaled OMP specific activity in the epithelium for each group of mice (Fig. 3). These "crossover" points were 4 days, 2 days, and 1 day for adult, young, and Triton-treated (regenerating) mice, respectively. A shift toward earlier crossover points in young and Triton-treated mice probably reflected both increased rate of transport and of turnover.

(3) The accelerated rates of OMP turnover in the bulb of young and regenerating mice were compensated by the increased isotope incorporation into OMP and transport from the epithelium. The differences in $T_{1 / 2}$ for OMP decline in the bulb among the three groups of mice were highly significant $(p=0.001)$ and may be correlated with the physiological state or developmental age of the primary neurons themselves, not with the absolute ages of the animals. Thus, OMP turnover rate was found to be lowest in adult mice and highest in adult regenerating mice. The dynamics of OMP turnover and transport in young mice ( 5 to 6 weeks) were intermediate to those of adult and regenerating mice.

Differences in OMP turnover in the bulb may reflect differences in cellular levels of OMP between groups of mice. Quantitative radioimmunoassays indicate that the young mice used in this study contained 50 to $100 \%$ of adult OMP levels (Margolis, 1980). As steady-state levels of OMP are reached in adult olfactory bulb, regulation 
of absolute levels at the nerve endings may proceed through decreased OMP turnover (as reflected in increasing $T_{1 / 2}$ for OMP decline). Maturing young olfactory neurons represent a higher proportion of the total neuronal population in young versus adult mice. In the Triton-treated animals, presumed synchronized regenerating neurons represent an even larger fraction of the neuronal population. Thus, the differences in OMP turnover among the groups of mice may be related to the magnitude of the subpopulation of maturing neurons.

Increased OMP turnover in the bulbs of young and Triton-treated (regenerating) mice is consistent with developmental studies of protein turnover in rat brain (Dunlop et al., 1977). Protein is metabolized in two pools: a slow pool with a $T_{1 / 2}$ of approximately 10 days and a rapid pool with a $T_{1 / 2}$ of approximately $15 \mathrm{hr}$. The rapidly turning over pool represented a higher proportion of metabolized protein in young versus adult brain, and overall rates of degradation and synthesis were higher in brain areas of young versus adult rats.

We have demonstrated that the specific activity of $\left[{ }^{35} \mathrm{~S}\right]$ methionine incorporated into OMP was approximately 4 and 6 times higher than free $\left[{ }^{35} \mathrm{~S}\right]$ methionine in young and regenerating mice, respectively. Glass and Doyle (1972) have demonstrated the applicability of determining first-order rate constants for decay from decline of pulse-labeled protein versus time only when precursor reutilization was minimized. This was corroborated by computer analyses in which true rate constants for protein turnover were calculated from apparent rate constants and residual precursor specific activities over the experimental time courses (Martin et al., 1977). The apparent $T_{1 / 2}$ 's for decline of OMP in olfactory tisues were not corrected by precursor recycling.

In addition to OMP, the dipeptide carnosine ( $\beta$-alanylL-histidine) is a marker for primary olfactory neurons. Previous studies have provided biochemical evidence for the role of carnosine as a neurotransmitter or neuromodulator at the first synapse in the olfactory bulb (see Margolis, 1980 for review). The turnover and transport characteristics of radiolabeled carnosine contrast markedly with those of OMP. Radiolabeled carnosine synthesized in olfactory epithelium was transported to the bulb within several hours, peaked in specific activity from 6 to $12 \mathrm{hr}$, and decayed with a half-life of approximately $20 \mathrm{hr}$ (Margolis and Grillo, 1977). In hamster olfactory bulb labeling intensity, monitored autoradiographically, peaked after $\left[{ }^{3} \mathrm{H}\right] \beta$-alanine (carnosine precursor) administration in the epithelium 3 days earlier than after $\left[{ }^{3} \mathrm{H}\right]$ $\alpha$-alanine administration (protein precursor) (Burd et al., 1982). Thus, the dipeptide carnosine manifests rapid transport and rapid turnover in contrast to OMP, which exhibits slow transport and slow turnover.

Thus, we have demonstrated that OMP behaves as a typical, slowly transported soluble protein as distinct from the dynamics of turnover and transport of the dipeptide carnosine. These studies help to define OMP as a marker of the physiological state of the primary olfactory neuron. The trend established in young mice compared to adult mice was accentuated in the Tritontreated (regenerating) group. Increased rates of isotope incorporation into OMP as well as the characteristics of its transport and turnover were reflective of a synchronized population of young, maturing neurons in adult mice. The dynamics of turnover and transport of OMP monitored as function of pharmacological or physiological manipulation of the primary olfactory system may prove useful in future studies.

\section{References}

Brady, S. T., and R. J. Lasek (1979) Nerve specific enolase and creatine phosphokinase are transported as part of the axoplasmic matrix (slow component b). Soc. Neurosci. Abstr. 5: 38.

Brady, S. T., M. Tytell, K. Heriot, and R. J. Lasek (1980) Calmodulin in axonal transport. Ann. N. Y. Acad. Sci. 356: 361-362.

Burd, G. D., B. J. Davis, F. Macrides, M. Grillo, and F. L. Margolis (1982) Carnosine in primary afferents of the olfactory system: An autoradiographic and biochemical study. J. Neurosci. 2: 244-255.

Cancalon, P. and J. S. Elam (1980) Rate of movement and composition of rapidly transported proteins in regenerating olfactory nerve. J. Neurochem. 35: 889-897.

Chiu, F. -C., B. Korey, and W. T. Norton (1980) Intermediate filaments from bovine, rat, and human CNS: Mapping analysis of the major proteins. J. Neurochem. 34: 1149-1159.

Dunlop, D., A. Lajtha, and J. Toth (1977) Measuring brain protein metabolism in young and adult rats. In Mechanisms, Regulation and Special Function of Protein Synthesis in the Brain, Elsevier/North Holland Biomedical Press, Amsterdam.

Erickson, P. F., and B. W. Moore (1980) Investigation of the axonal transport of three acidic, soluble proteins (14-3-2, 14$3-3$, and $\mathrm{S}-100)$ in the rabbit visual system. J. Neurochem. 35: $232-241$.

Farbman, A. I., and F. L. Margolis (1978) Immunocytochemical studies of the olfactory marker protein in developing olfactory mucosa of mice and rats. Anat. Rec. 190: 392.

Farbman, A. I., and F. L. Margolis (1980) Olfactory marker protein during ontogeny: Immunohistochemical localization. Dev. Biol. 74: 205-215.

Garner, J. A., and R. J. Lasek (1982) Cohesive axonal transport of the slow component b complex of polypeptides. J. Neurosci. 2: 1824-1835.

Glass, R. D., and D. Doyle (1972) On the measurement of protein turnover in animal cells. J. Biol. Chem. 247: 52345242.

Goldberg, A. L., and J. F. Dice (1974) Intracellular protein degradation in mammalian and bacterial cells. Annu. Rev. Biochem. 43: 835-869.

Grafstein, B. (1971) Role of slow axonal transport in nerve regeneration. Acta Neuropathol. Suppl. 5: 144-152.

Grafstein, B., and D. S. Forman (1980) Intracellular transport in neurons. Physiol. Rev. 60: 1167-1283.

Graziadei, P. P. C. (1973) Cell dynamics in the olfactory mucosa. Tissue Cell 5: 113-131.

Graziadei, P. P. C., and G. A. Monti-Graziadei (1978) The olfactory system: A model for the study of neurogenesis and axon regeneration in mammals. In Neuronal Plasticity, C. Cotman, ed., pp. 133-153, Raven Press, New York.

Gross, G. W., and L. M. Beidler (1973) Fast axonal transport in the C-fibers of garfish olfactory nerve. J. Neurobiol. 4: 413-428.

Harding, J., P. P. C. Graziadei, G. A. Monti-Graziadei, and F. L. Margolis (1977) Denervation in the primary olfactory pathway of mice. IV. Biochemical and morphological evidence for neuronal replacement following nerve section. Brain Res. 132: 11-28. 
Hartman, B. K., and F. L. Margolis (1975) Immunofluorescence localization of the olfactory marker protein. Brain Res. 96 : 176-180.

Keller, A., and F. L. Margolis (1975) Immunological studies of the rat olfactory marker protein. J. Neurochem. 24: 11011106.

Keller, A., and F. L. Margolis (1976) Isolation and characterization of rat olfactory marker protein. J. Biol. Chem. 251: 6232-6237.

Kream, R. M., R. S. Zukin, and G. B. Stefano (1980) Demonstration of two classes of opiate binding sites in the nervous tissue of the marine mollusc Mytilus edulis. J. Biol. Chem. 255: 9218-9224.

Lajtha, A., and D. Dunlop (1981) Turnover of protein in the nervous system. Life Sci. 29: 755-767.

Margolis, F. L. (1972) A brain protein unique to the olfactory bulb: Isolation and immunological studies. Proc. Natl. Acad. Sci. U. S. A. 69: 1221-1224.

Margolis, F. L. (1974) Carnosine in the primary olfactory pathway. Science 184: 909-911.

Margolis, F. L. (1980) A marker protein for the olfactory chemoreceptor neuron. In Proteins of the Nervous System, Ed. 2, R. A. Bradshaw and D. M. Schneider, eds., pp. 59-84, Raven Press, New York.

Margolis, F. L. (1982) Olfactory marker protein (OMP). Scand. J. Immunol. 15 (Suppl. 9): 181-199.

Margolis, F. L., and M. Grillo (1977) Axoplasmic transport of carnosine ( $\beta$-alanyl-L-histidine) in the mouse olfactory pathway. Neurochem. Res. 2: 507-519.

Margolis, F. L., and J. F. Tarnoff (1973) Site of biosynthesis of the mouse brain olfactory bulb protein. J. Biol. Chem. 248: 451-455.

Martin, A. F., M. Rabinowitz, R. Blough, G. Prior, and R. Zak (1977) Measurements of half-life of rat cardiac myosin heavy chain with leucyl-tRNA used as precursor pool. J. Biol. Chem. 252: 3422-3429.

McQuarrie, I. G., and B. Grafstein (1982) Protein synthesis and fast axonal transport in regenerating goldfish retinal ganglion cells. Brain Res. 235: 213-223.

Monti-Graziadei, G. A., F. L. Margolis, J. W. Harding, and P. P. C. Graziadei (1977) Immunocytochemistry of the olfactory marker protein. J. Histochem. Cytochem. 25: 1311-1316.
Monti-Graziadei, G. A., R. S. Stanley, and P. P. C. Graziadei (1980) The olfactory marker protein in the olfactory system of the mouse during development. Neuroscience 5: 12391252.

Nadi, N. S., and F. L. Margolis (1978) A simple method for the elimination of amine contaminants in buffers for singlecolumn amino acid analysis in physiological samples at picomole levels. Anal. Biochem. 91: 180-185.

Nadi, N. S., R. Head, M. Grillo, J. Hempstead, N. GrannotReisfeld, and F. L. Margolis (1981) Chemical deafferentation of the olfactory bulb: Plasticity of the levels of tyrosine hydroxylase, dopamine and norepinephrine. Brain Res. 213: 365-377.

Neville, D. M., Jr. (1971) Molecular weight determinations of protein-dodecyl sulfate complexes by gel electrophoresis in a discontinuous buffer system. J. Biol. Chem. 246: 6328-6334.

Oakley, B. R., D. R. Kirsch, and N. R. Morris (1980) A simplified ultrasensitive silver stain for detecting proteins in polyacrylamide gels. Anal. Biochem. 105: 361-363.

Poole, B. (1971) The kinetics of disappearance of labelled leucine pool of rat liver and its effects on the apparent turnover of catalase and other hepatic proteins. J. Biol. Chem. 246: 6587-6591.

Sedmak, J. J., and S. E. Grossberg (1977) A rapid, sensitive and versatile assay for protein using Coomassie brilliant blue G250. Anal. Biochem. 79: 544-552.

Stein, S., P. Bohlen, J. Stone, W. Dairman, and S. Udenfriend (1973) Amino acid analysis with Fluorescamine at the picomole level. Arch. Biochem. Biophys. 155: 202-212.

Tytell, M., M. M. Black, J. A. Garner, and R. J. Lasek (1981) Axonal transport: Each major rate component reflects the movement of distinct complexes. Science 214: 179-180.

Weiss, P. A., and Y. Holland (1965) Neuronal dynamics and axonal flow. II. The olfactory nerve as model test object. Proc. Natl. Acad. Sci. U. S. A. 57: 258-264.

Wenthold, R. J., and M. L. McGarvey (1982) Different polypeptides are rapidly transported in auditory and optic neurons. J. Neurochem. 39: 27-35.

Willard, M., W. M. Cowan, and P. R. Vagelos (1974) The polypeptide composition of intra-axonally transported proteins: Evidence for four transport velocities. Proc. Natl. Acad. Sci. U. S. A. 71: 2183-2187. 